\title{
The Role of Interests and Talents in the Competency Skills of Students
}

\author{
Lindawati $^{1 *}$, Achmad Wahidy ${ }^{1}$, Happy Fitria ${ }^{1}$ \\ ${ }^{1}$ Universitas PGRI Palembang, Indonesia \\ "Corresponding author. Email: sitimunajah970@gmail.com
}

\begin{abstract}
This study aims to prove the role of interests and talents in improving student competency skills. This research was conducted using descriptive qualitative methods through observation, interviews and documentation to identify the dominant learning styles and multiple intelligences in students. The results of the research on the interests and talents of the 12 students who were the object of this study showed the dominant kinesthetic learning style was 11 students $(92 \%)$. The dominant learning style of students is kinesthetic learning through movement, touching, and doing. Multiple intelligence shows the kinesthetic intelligence of 7 people $(58 \%)$, namely identifying, varying and multiplying activities, exploring pleasure. 11 people $(92 \%)$ interpersonal intelligence which is a person's ability to establish good social relationships. The indicators are empathy, pro-social, self-awareness, problem solving skills and effective communication. The dominant intelligence possessed by students is the basis for teachers in increasing their spiritual, social, knowledge and skills competencies both in academic and non-academic achievements according to their interests and talents.
\end{abstract}

Keywords: Interests, Talents, Skills Competence

\section{INTRODUCTION}

Improving the quality of education is one of the main pillars of education development in Indonesia. Quality education will produce intelligent, competitive human resources (HR) in accordance with the vision of the Ministry of National Education in 2025 [1]. The quality of education refers to the standards set out in Government standards are the minimum criteria regarding the education system in all jurisdictions of the Republic of Indonesia which serve as the basis for planning, implementing, and supervising education in each education unit in the context of realizing quality national education. The SNP contains provisions on eight standards that are aspired to be realized in all educational units at a certain time.

The results of observations during learning in the research class found that most of the students' abilities of SD 232 Palembang in the learning process were less enthusiastic and enthusiastic in receiving learning material. Both learning activities in the classroom or extracurricular activities. The lack of student activity in the learning process and having difficulty expressing what is in the mind and feelings of students with a quiet character (introvert), difficulty speaking, thinking about consequences, long adaptation, lack of stimulation, lack of student ability to explore abilities. There are a lot of students' skills in observing objects or pictures that cannot find information from the images or objects displayed.

There are still very few people who actively ask questions in the learning process or outside of the learning process in the series of questions activity. Lack of motivation from parents and teachers' motivation as an inner factor serves to generate, underlie, direct the learning process. High motivation to learn can determine whether or not to achieve goals so that the greater the motivation, the greater the learning success. Early extracurricular activities, the researchers found that most students were not interested in extracurricular activities at school, both scouting, dance and Mathematics and Natural Sciences classes, so that during the implementation the students were not enthusiastic and excited. In learning activities that use motoric, it has not resulted in satisfactory achievements. Most of the teachers have not been able to identify students' interests and talents. The teacher's lack of enthusiasm in guiding students in developing and directing the interests and talents of grade IV, V, VI students is because these class students have entered the age of around 9-13 years, at which time this age is the transition age to the real world when students' cognitive abilities develop to plan. something.

Based on the above problems, the researchers are interested in conducting research on the role of interests and talents in improving student competency skills 
through the learning modality test and talent interest by using observation, interview and documentation techniques.

By identifying students' interests and talents, teachers will be able to direct what intelligence they have and channel it, receive guidance, and will improve the competence of students' skills in academic and nonacademic fields. Giving equal opportunities essentially means working on an environment where all students get the same opportunity to realize their potential optimally according to the students' interests and talents. To identify students' interests and talents both academic and non-academic. By identifying the interests and talents of students and the efforts of teachers so as to increase the competence of achievement skills both academic and non-academic.

According to Apriana, et al [2] interest is a mental state that results in a directed response to a particular situation or object that is pleasant and satisfies it (satisfiers). This definition explains that interest functions as a driving force that directs a person to carry out certain activities Specific.

According to Sandjaja [3] interest is a tendency that causes someone to try to find or try activities in certain fields. Interest is also defined as a positive attitude towards environmental aspects. In addition, interest is also a constant tendency to pay attention to and enjoy an activity accompanied by pleasure.

According to Kearney [4] interest is a desire that is driven by a desire after seeing, observing and comparing and considering the needs it wants.

\section{METHODS}

Researchers have observed the learning process both classroom learning and learning outside the classroom (extracurricular) and are involved in it. Recording and evaluating strengths, weaknesses, opportunities and threats with analysis then the researcher prepares a number of questions that have been compiled and conducts interviews based on or guides these questions. When students respond or give their views on the questions asked, the interviewer records the answers. Then the researcher continues other questions that have been compiled or provided. The same question will then be asked to each person as many as 12 students as resource persons in the scheduled time with 27 interviews with learning modalities and 80 questions on multiple intelligences as a reference for the aptitude interest test.

\section{RESULTS AND DISCUSSION}

Competency skills with kinesthetic intelligence 7 people (58\%) from 12 students according to the interests of students' talents. Kinesthetic intelligence is a person's ability to use his entire body or body to express ideas and feelings, as well as the skill to use his hands to change or create something.

Having to move and do activities always moving his feet, jumping around, tapping his fingers, and often like never being able to sit still. They learn through body movement and touch and have a great memory. Learn fast and have a strong memory of what is done with movement. Have a talent for physical activity that is[5] prominent in running, swimming, dancing and other sports activities. Movement is highly coordinated and has good instincts regarding body, space and time.

To improve students' competency skills with kinesthetic intelligence by combining kinesthetic style learning models because they get bored faster with those who just sit still and listen to the lesson. Students with kinesthetic intelligence like learning styles using objects, doing experiments and physical tasks that are carried out repeatedly, role playing exercises and getting involved then telling their feelings after doing these activities. Exercising balance by dancing, training the alignment of motion, strength and flexibility of muscles.

Increase skill competency with kinesthetic intelligence that matches talent interests by imitating, manipulating, demonstrating, coordinating, creating a healthy gymnastic movement.

The results of the interview increased the competence of interpersonal intelligence skills by 11 people $(92 \%)$ out of 12 students. Interpersonal intelligence is to develop and create new social relationships effectively so that they can empathize and understand others completely.

Students who have interpersonal intelligence can communicate well when in class and in other interaction environments, can express opinions clearly both in person and in public, are happy and fit to work in groups, can be good leaders. In delegating roles and responsibilities for each group member and managing interpersonal relationships when there are differences. more sensitive to emotions and situations around him only through simple interactions. Very confident in using his talents in cooperating with others, respecting other people's knowledge, even in large groups.

Have high solidarity with other people, understand what other people are experiencing or have felt. feel happy about the success of others, can be a good listener, can be a counselor or provide advice according to capacity.

Providing different activities, it gives an emotional experience that remains in the memory with camping, sports, or other social activities that require meeting new people. This is a very effective way to understand other people's perspectives and also learn to communicate [6]. 
Teachers can improve students' competency skills with interpersonal intelligence by sharpening empathy by providing simple examples by helping others, giving assistance to friends. Teaching students not to discriminate against differences in physical, religious, racial and social status in making friends because all are God's creations, differences do not make each other hostile and hate each other. When you feel sad and disappointed don't hesitate to express it because it is a natural expression and can be managed well.

Get in the habit of asking how students feel in their activities. Providing understanding to students in order to know how to manage good emotions when they are angry, disappointed, confused by students so that they can express their feelings in a good way so that they can successfully maintain good relationships with everyone [6]. Having students who have more abilities stay humble by continuing to increase their level of selfconfidence.

Increasing the skill competency of students who have interpersonal intelligence can be done by following, implementing, controlling, overcoming and determining [7]. For example, students can follow (imitate) provide assistance to friends from what they see, then students can apply it in activities to help others, students can control themselves when they feel disappointed over when people they have helped ignore, students can overcome their disappointment [8] remaining wise in controlling their emotions and then students will be able to determine the attitude or actions that must be done whether happy or disappointed or sad because of someone's treatment or actions against him [9].

\section{CONCLUSION}

Identify the interests and talents of students aged 1013 by increasing the variety of activities, stimulating students to choose activities they like. directing and guiding, exploring the pleasures to which his talents will interest him

The teacher as a facilitator provides methods, varied learning models in accordance with the learning modalities of elementary school students who predominantly use body movements (kinesthetic). Conduct an interest aptitude test by identifying multiple learning modalities and intelligences [10].

When the students' interests and talents can be identified and grouped into activities that are in accordance with the students' learning modalities and multiple intelligences, the competence of students' skills will increase, so students can apply the appropriate learning style and according to their learning style, so that students can maximize academic and non-academic learning achievement.

\section{ACKNOWLEDGMENTS}

Our deepest gratitude goes to Chancellor of Palembang PGRI University, Director of the Postgraduate Program of PGRI Palembang University and the Education Management Study Program of PGRI Palembang University, who have supported us in doing this extraordinary thing. This project is funded independently. We also want to thank our Education Management friends who helped us a lot in a short time frame to complete this project.

\section{REFERENCES}

[1] Peraturan Pemerintah Nomor 19 Tahun 2005 tentang Standar Nasional Pendidikan [Government Regulation Number 19 of 2005 concerning National Education Standards].

[2] Apriana, D., Kristiawan, M., \& Wardiah, D. (2018) Headmaster's Competency in Preparing Vocational School Students for Entrepreneurship International Journal of Scientific \& Technology Research Volume 8, Issue 08, Issn 2277-861.

[3] Fitria, et al. (2020) Model Pembelajaran Kreatif Dalam Meningkatkan Minat Membaca Siswa Di Luar Sekolah [Creative Learning Model in Increasing Student Reading Interest Outside of School Proceedings of the National Education]. Prosiding Seminar Nasional Pendidikan Program Pascasarjana Universitas PGRI Palembang 10 Januari 2020.

[4] Kearney, K. L. (2010). Students' Self-Concept and Perceptions of Mentoring Relationships in a Summer Mentorship Program for Talented Adolescents

https://www.tandfonline.com/author/Little $\% 2 \mathrm{C}+\mathrm{Ca}$ therine+ $\mathrm{A}$

[5] Olszewski, P. (2018) The Role of the Family in Talent Development Handbook of Giftedness in Children.

[6] Olszewsk, P., Rena, F. K. Subotnik, F.C. W. (2015) Conceptualizations of Giftedness and the Development of Talent: Implications for Counselors. Journal Counseling and Development. https://doi.org/10.1002/j.1556-6676.2015.00190.x

[7] Pollar, E. (2009). Exploring the Relationship of College Freshmen Honors Students' Effort and Ability Attribution, Interest, and Implicit Theory of Intelligence with Perceived Ability.Sage Journal https://doi.org/10.1177\%2F0016986209355975

[8] Saifudin. (2013). Perkembangan Peserta Didik [Talent and Characteristics of Talented Students]. Jakarta: Rineka Cipta.

[9] Usman, H. (2013). Manajemen Teori, Praktik, dan Riset Pendidikan [Management Theory, 
Practice, and Educational Research]. Jakarta: Bumi Aksara.

[10] Rohiat. (2014). Kecerdasan Kepemimpinan Kepala Sekolah [Principal Leadership Intelligence]. Bandung: PT Refika Aditama. 